Journal of Finance Research

\title{
Study on the Follow-up Measurement of Goodwill of Listed Companies
}

\author{
Yan Zhuang $^{1}$ Youcai Xiang ${ }^{2 *}$
}

1. Honor College, Nanjing Normal University, Nanjing, Jiangsu, 210023, China

2. Ginling College, Nanjing Normal University, Nanjing, Jiangsu, 210023, China

\begin{tabular}{l}
\hline ARTICLE INFO \\
\hline Article history \\
Received: 17 August 2020 \\
Revised: 21 August 2020 \\
Accepted: 9 October 2020 \\
Published Online: 16 October 2020
\end{tabular}

Keywords:

Consolidated goodwill

Follow-up measurement

Impairment test

\begin{abstract}
Nowadays, the wave of mergers and acquisitions in the capital market is still surging. High evaluation does bring high performance, and the huge impairment of goodwill has become a key factor for the frequent Black Swan events of listed companies. Starting from the essence of goodwill, using Chinese A-share listed companies from 2007 to 2019 as samples and based on the market data, distribution analysis and performance impact, this paper argues that problems of goodwill impairment in China are incomplete accounting standards, inexhaustive impairment implementation and incomprehensive market supervision, thus giving reasonable suggestions. Proper follow-up measurement of goodwill is conducive to improving accounting information quality and adapting to capital market demands, which is of great significance to the revision of international standards.
\end{abstract}

\section{Introduction}

$\mathrm{T}$ The wave of mergers and acquisitions of A-share listed companies and the continued increase of the goodwill book value have recently made the goodwill impairment risk prominent. Wind data show that, as of the end of 2019, there are 3,839 listed companies in Shanghai and Shenzhen A-share markets, with a total goodwill of 1.26 trillion yuan and goodwill impairment of 3.816 billion yuan, accounting for $6.63 \%$ of net profit. And goodwill impairment risk once outbreaks, it will distort the market resource allocation while bringing a fatal blow to the normal operation of enterprises. Accounting treatment has a direct impact on whether trillion of goodwill becomes a bubble and whether pressure of impairment can be alleviated.

\section{Goodwill}

\subsection{The Essence of Goodwill}

Goodwill was first used in legal disputes in the $16^{\text {th }}$ century ${ }^{[1]}$, then defined by the British judiciary as all the advantages obtained by an enterprise in its going concern $^{[2]}$, defined in the $19^{\text {th }}$ century as the profits earned by continuous consumption of customers' goodwill ${ }^{[3]}$ and in the $20^{\text {th }}$ century as the general term for all the reasons for excessive profits ${ }^{[4]}$. At present, it is generally believed that goodwill is the accumulated potential value that can bring future economic benefits to the enterprise in the process of operation, which can be quantified as the acquisition premium between the investment cost paid by the acquiring enterprise and the net assets of the acquired enterprise in M\&A.

*Corresponding Author:

Youcai Xiang,

Ginling College, Nanjing Normal University, No. 1 Wenyuan Road, Qixia District, Nanjing, Jiangsu, 210023, China;

E-mail:xiangyoucai@njnu.edu.cn. 
The essence of goodwill has always been controversial, and the more influential viewpoints include the synergistic effect theory, the ternary theory and the core goodwill theory.

The synergetic effect theory (Hermann Haken, 1971) ${ }^{[5]}$ is applied in the field of goodwill to form the view that goodwill is the synergetic effect among enterprise elements, and the cooperation among various elements makes the overall comprehensive value higher than the sum of each individual value. Goodwill makes excessive profits on account of the positive synergies between internal factors and external environment, thus creating new value.

The ternary theory (Eldon S Hendriksen, 1977) ${ }^{[6]}$ can be divided into favorable value theory, excess earning theory and master valuation account theory. According to the favorable value theory, goodwill is the subjective favorable impression generated by customers due to corporate image or related interests, which cannot be measured and recorded. According to the excess earning theory, goodwill is the part where the present value of an enterprise's expected profit exceeds the normal level. According to the master valuation account theory, goodwill is the difference between the overall value of an enterprise and the fair value of its identifiable net assets. Among them, the master valuation account theory has been widely recognized for its quantifiable advantages, but the current accounting standards in China only recognize the difference generated by M\&A and do not include the internally generated goodwill. $^{[7]}$

The core goodwill theory (FASB, 1999) ${ }^{[8]}$ believes that goodwill consists of six elements: the difference between the fair value of the acquiree's net assets and its book value at the acquisition date; the fair value of the acquiree's other unrecognized net assets; the fair value of the going concern component of the acquiree's ongoing business; the fair value of synergies between the acquirer and the acquiree's net assets and business; the amount overmeasured by the acquirer due to errors in measuring the acquisition offer; and the difference between the amount paid by the acquirer and the normal level due to an incorrect estimate.

This paper holds that goodwill is the capitalized value between a listed company's future economic earnings and the normal profitability of its identifiable net assets.

\subsection{Follow-up Measurement of Goodwill}

At present, goodwill impairment is the main way for listed companies to measure goodwill. Goodwill impairment means that the enterprise shall conduct impairment test on goodwill annually, and if any impairment occurs, it is required to truthfully disclose and make provision for impairment.

China Accounting Standards Committee (CASC) once issued the Corporate Accounting Standards Update (9th Issue, 2018), announcing the feedback of the advisory committee on the topic of goodwill and its impairment, which indicated that most of the advisory committee members approved the change of the current operation of goodwill impairment to goodwill amortization. In June 2020, the International Accounting Standards Board (IASB) presented its preliminary opinions in the discussion draft of Business CombinationsDisclosures, Goodwill and Impairment in the seminar, in view of the cost and effect of goodwill impairment, that goodwill amortization should not be reintroduced for the time being.

Due to the fact that when the purchased goodwill is actually recognized in the current criteria, in addition to its reasonable value, it is also affected by other factors such as valuation deviation and agency deviation, scholars have proposed that goodwill can be divided into recognized and unrecognized (Wang Jing, 2015) ${ }^{[9]}$. The recognized one adopts the yearly impairment test method. The unrecognized one is divided into valuation and agency deviation, unrecognized assets and liabilities, the former of which directly writes down the capital surplus while the latter is disclosed in financial statements.

Some scholars also expressed that the change of goodwill impairment to amortization could not solve the problem (Zhang Xinyuan, 2017) ${ }^{[10]}$, so it should return to the disadvantages of the impairment test method itself and make up for them, such as refining the standard of judgment of goodwill impairment, optimizing the process of goodwill impairment test and strengthening the supervision of mergers and acquisitions of listed companies.

Additionally, the insistence on using a combination of amortization and impairment test for subsequent measurement of goodwill (Zhang Naijun, 2018) ${ }^{[11]}$ is based on the fact that the current system does not conform to the principle of accounting prudence and matching principle, and the combination of the two is conducive to risk reduction in the current active capital market.

The amortization method should be reintroduced (Tan Yawen, 2019) ${ }^{[12]}$, the rationale of which is that the current impairment test method relies too much on management's subjective judgment, and the costly and complicated process is prone to errors. The combination of the two can reduce costs and difficulties and urge the management to cautiously recognize goodwill from a longer perspective. 


\section{Status Quo of Goodwill Impairment of Listed Companies in China}

\subsection{Scale of Goodwill Impairment}

In order to study the value of goodwill and its impairment, this paper selects all A-share listed companies in Shanghai and Shenzhen from 2007 to 2019 for data analysis based on Wind database.

\subsubsection{Descriptive Statistical Analysis of the Book Value of Goodwill}

Table 1. Statistical analysis of the book value of goodwill ${ }^{\mathbb{1}}$

\begin{tabular}{|c|c|c|c|c|c|}
\hline Year & $\begin{array}{c}\text { Total book } \\
\text { value of } \\
\text { goodwill } \\
(100 \text { million } \\
\text { yuan })\end{array}$ & $\begin{array}{c}\text { Number } \\
\text { of A-share } \\
\text { listed com- } \\
\text { panies }\end{array}$ & $\begin{array}{c}\text { Number of } \\
\text { companies } \\
\text { with good- } \\
\text { will }\end{array}$ & $\begin{array}{c}\text { Mean val- } \\
\text { ue (100 } \\
\text { million } \\
\text { yuan) }\end{array}$ & $\begin{array}{c}\text { Maximum } \\
\text { value (100 } \\
\text { million } \\
\text { yuan) }\end{array}$ \\
\hline 2007 & 419.55 & 1479 & 545 & 0.77 & 156.90 \\
\hline 2008 & 813.69 & 1532 & 623 & 1.31 & 143.28 \\
\hline 2009 & 872.60 & 1678 & 679 & 1.28 & 141.63 \\
\hline 2010 & 942.42 & 2027 & 750 & 1.26 & 119.56 \\
\hline 2011 & 1356.06 & 2306 & 919 & 1.48 & 132.05 \\
\hline 2012 & 1674.81 & 2453 & 1070 & 1.57 & 138.40 \\
\hline 2013 & 2106.77 & 2463 & 1202 & 1.75 & 121.81 \\
\hline 2014 & 3427.67 & 2588 & 1350 & 2.54 & 120.37 \\
\hline 2015 & 6473.76 & 2806 & 1571 & 4.12 & 455.89 \\
\hline 2016 & 10599.74 & 3029 & 1710 & 6.20 & 460.97 \\
\hline 2017 & 13105.85 & 3462 & 1901 & 6.89 & 419.34 \\
\hline 2018 & 13232.81 & 3563 & 2032 & 6.51 & 401.28 \\
\hline 2019 & 12572.34 & 3839 & 2088 & 6.02 & 428.08 \\
\hline
\end{tabular}

Overall, total book value of goodwill has shown a steady rise, with only a brief decline from 2018 to 2019 . Since 2014, the book value of goodwill has shown a doubling trend, growing from 342.767 billion yuan to 1.059974 trillion yuan in just two years. It can be seen that listed companies have attached great importance to the significant influence of goodwill on financial statements year by year, while the explosive mergers and acquisitions have made the value of goodwill soaring, thus accumulating a considerable amount of goodwill impairment risk. In contrast, in the past three years, the book value has been generally stable, even with a slight regression, which shows that the follow-up measurement and accounting

(1) Upon inquiry, all the minimum value is 1 yuan, which is represented by Shanghai Jion Buy and Hengdian Group DMEGC Magnetics claiming that value of goodwill cannot be reasonably estimated so as to change into an intangible asset accounting, amortization and provision for large impairment. treatment of goodwill after frequent Black Swan events has become a difficult problem.

From the perspective of the maximum and average book value of goodwill, the maximum value increased vertiginously in 2015, about four times that of the previous year, and then fluctuated. Compared with the maximum value, the average value is at an awkward level, indicating a high degree of polarization in the book value of goodwill.

\subsubsection{Descriptive Statistical Analysis of Goodwill Impairment Loss}

Table 2. Statistical analysis of goodwill impairment loss ${ }^{2}$

\begin{tabular}{|c|c|c|c|c|c|}
\hline Year & $\begin{array}{c}\text { Total goodwill } \\
\text { impairment loss } \\
\text { (100 million } \\
\text { yuan) }\end{array}$ & $\begin{array}{c}\text { Num- } \\
\text { ber of } \\
\text { impaired } \\
\text { compa- } \\
\text { nies }\end{array}$ & $\begin{array}{c}\text { Average } \\
\text { value (10 } \\
\text { million } \\
\text { yuan) }\end{array}$ & $\begin{array}{c}\text { Maximum } \\
\text { value (100 } \\
\text { million yuan) }\end{array}$ & $\begin{array}{c}\text { Median } \\
(10 \text { million } \\
\text { yuan) }\end{array}$ \\
\hline 2007 & 5.44 & 50 & 1.09 & 2.39 & 0.32 \\
\hline 2008 & 23.16 & 82 & 2.82 & 9.19 & 0.30 \\
\hline 2009 & 7.56 & 68 & 1.11 & 1.75 & 0.45 \\
\hline 2010 & 12.77 & 63 & 2.03 & 2.38 & 0.47 \\
\hline 2011 & 13.29 & 73 & 1.82 & 2.92 & 0.26 \\
\hline 2012 & 10.67 & 95 & 1.12 & 1.66 & 0.35 \\
\hline 2013 & 17.09 & 138 & 1.24 & 1.45 & 0.50 \\
\hline 2014 & 32.28 & 162 & 1.99 & 2.50 & 0.65 \\
\hline 2015 & 77.49 & 249 & 3.11 & 6.16 & 0.83 \\
\hline 2016 & 101.31 & 345 & 2.94 & 6.53 & 0.89 \\
\hline 2017 & 349.48 & 460 & 7.60 & 12.59 & 1.39 \\
\hline 2018 & 1600.10 & 831 & 19.26 & 40.59 & 3.63 \\
\hline 2019 & 318.16 & 724 & 4.39 & 9.42 & 2.58 \\
\hline
\end{tabular}

In general, goodwill impairment loss showed a wavy growth trend from 2007 to 2014, only with a slightly decline in 2008, related to the economic downturn in that year. From 2014 to 2018, goodwill impairment loss began to rise sharply, almost doubling each year, 2015 for the previous year twice, 2017 for the previous year three times and 2018 for the previous year four times. The number of goodwill impairment companies increased by $412.96 \%$ from 162 in 2014 to 831 in 2018, and goodwill impairment loss increased by $4856.93 \%$ from 3.228 billion yuan in 2014 to 160.01 billion yuan in 2018. By 2019, however, the impairment loss fell precipitously and recovered to a level comparable to that of 2017, mainly due to the large amount of impairment losses collectively recorded by enterprises in 2018 .

In terms of the maximum value of goodwill impairment loss, there was a breakneck rise in 2008 and 2018. Com-

(2) The above table excludes listed companies with negative goodwill impairment loss due to the cancellation of subsidiaries, etc. The number of impairment companies excludes listed companies with impairment losses equal to zero, and the mean and median are calculated based on the number of impairment companies. 
bining the mean and median, it can be found that the gap between the two indicates that some listed companies have made a large amount of impairment provisions, directly pulling up the overall data and reflecting the polarization issue.

\subsubsection{Concentration Analysis of Goodwill Book Value}

The above table shows that the book value of goodwill has been yearly increasing since 2007, while the proportion of the top ranking companies in the overall market has been yearly decreasing basically, which reveals that more listed companies participate in the goodwill recognition and the phenomenon of mergers and acquisitions has gradually become normalized so that goodwill is no longer unique to large enterprises. At the same time, the top 20 listed companies still account for nearly $25 \%$ in recent years, demonstrating that a small number of enterprises have huge goodwill, and the concentration degree of goodwill book value is still in a relatively high state.

\subsubsection{Concentration Analysis of Goodwill Impair- ment Loss}

As can be seen from the above table, goodwill impairment losses are also increasing annually while the proportion of the top listed companies is decreasing annually, which is similar to the trend of goodwill book value. Goodwill impairment loss of the top 20 listed companies also accounts for about $25 \%$ recently and there are still a few enterprises with high impairment provision and several enterprises with little or no impairment provision

Table 3. Concentration analysis of goodwill book value

\begin{tabular}{|c|c|c|c|c|c|c|c|c|c|c|}
\hline Year & $\begin{array}{c}\text { Total book } \\
\text { value of } \\
\text { goodwill (100 } \\
\text { million yuan) }\end{array}$ & $\begin{array}{c}\text { Maximum } \\
\text { value (100 } \\
\text { million } \\
\text { yuan) }\end{array}$ & $\begin{array}{c}\text { Top 5 total } \\
\text { amount (100 } \\
\text { million } \\
\text { yuan) }\end{array}$ & $\begin{array}{c}\text { Top 10 total } \\
\text { amount (100 } \\
\text { million } \\
\text { yuan) }\end{array}$ & $\begin{array}{c}\text { Top 15 total } \\
\text { amount (100 } \\
\text { million } \\
\text { yuan) }\end{array}$ & $\begin{array}{c}\text { Top 20 total } \\
\text { amount (100 } \\
\text { million yuan) }\end{array}$ & $\begin{array}{c}\text { Top 5 } \\
\text { amount } \\
\text { proport-ion }\end{array}$ & $\begin{array}{c}\text { Top 10 } \\
\text { amount } \\
\text { proport-ion }\end{array}$ & $\begin{array}{c}\text { Top 15 } \\
\text { amount } \\
\text { proport-ion }\end{array}$ & $\begin{array}{c}\text { Top 20 } \\
\text { amount } \\
\text { proport-ion }\end{array}$ \\
\hline 2007 & 419.55 & 156.90 & 225.33 & 266.93 & 291.93 & 307.77 & $54 \%$ & $64 \%$ & $70 \%$ & $73 \%$ \\
\hline 2008 & 813.69 & 143.28 & 431.93 & 536.49 & 600.46 & 633.01 & $53 \%$ & $66 \%$ & $74 \%$ & $78 \%$ \\
\hline 2009 & 872.60 & 141.63 & 420.92 & 524.12 & 590.23 & 632.65 & $48 \%$ & $60 \%$ & $68 \%$ & $71 \%$ \\
\hline 2010 & 942.42 & 119.56 & 428.23 & 544.18 & 613.45 & 655.98 & $45 \%$ & $58 \%$ & $65 \%$ & $70 \%$ \\
\hline 2011 & 1356.06 & 132.05 & 487.27 & 742.54 & 834.49 & 898.12 & $36 \%$ & $55 \%$ & $62 \%$ & $66 \%$ \\
\hline 2012 & 1674.81 & 138.40 & 512.98 & 760.04 & 858.85 & 935.99 & $31 \%$ & $45 \%$ & $51 \%$ & $56 \%$ \\
\hline 2013 & 2106.77 & 121.81 & 530.00 & 817.99 & 953.96 & 1051.52 & $25 \%$ & $39 \%$ & $45 \%$ & $50 \%$ \\
\hline 2014 & 3427.67 & 120.37 & 522.42 & 870.91 & 1054.61 & 1193.24 & $15 \%$ & $25 \%$ & $31 \%$ & $35 \%$ \\
\hline 2015 & 6473.76 & 455.89 & 881.98 & 1264.20 & 1537.30 & 1772.61 & $14 \%$ & $20 \%$ & $24 \%$ & $27 \%$ \\
\hline 2016 & 10599.74 & 460.97 & 1295.88 & 1961.91 & 2425.47 & 2779.01 & $12 \%$ & $19 \%$ & $23 \%$ & $26 \%$ \\
\hline 2017 & 13105.85 & 419.34 & 1342.73 & 2055.13 & 2562.20 & 2985.17 & $10 \%$ & $16 \%$ & $20 \%$ & $23 \%$ \\
\hline 2018 & 13232.81 & 401.28 & 1361.69 & 2130.79 & 2715.99 & 3168.72 & $10 \%$ & $16 \%$ & $21 \%$ & $24 \%$ \\
\hline 2019 & 12572.34 & 428.08 & 1408.87 & 2256.69 & 2836.69 & 3292.68 & $11 \%$ & $18 \%$ & $23 \%$ & $26 \%$ \\
\hline
\end{tabular}

Table 4. Concentration analysis of goodwill impairment loss

\begin{tabular}{|c|c|c|c|c|c|c|c|c|c|c|}
\hline Year & $\begin{array}{l}\text { Total good- } \\
\text { will impair- } \\
\text { ment loss } \\
\text { (100 million } \\
\text { yuan) }\end{array}$ & $\begin{array}{c}\text { Maximum } \\
\text { value (100 } \\
\text { million yuan) }\end{array}$ & $\begin{array}{c}\text { Top } 5 \text { total } \\
\text { amount (100 } \\
\text { million yuan) }\end{array}$ & $\begin{array}{l}\text { Top } 10 \text { total } \\
\text { amount (100 } \\
\text { million yuan) }\end{array}$ & $\begin{array}{l}\text { Top } 15 \text { total } \\
\text { amount (100 } \\
\text { million yuan) }\end{array}$ & $\begin{array}{l}\text { Top } 20 \text { total } \\
\text { amount (100 } \\
\text { million yuan) }\end{array}$ & $\begin{array}{c}\text { Top } 5 \\
\text { amount } \\
\text { proport-ion }\end{array}$ & $\begin{array}{c}\text { Top } 10 \\
\text { amount } \\
\text { proport-ion }\end{array}$ & $\begin{array}{c}\text { Top } 15 \\
\text { amount pro- } \\
\text { port-ion }\end{array}$ & $\begin{array}{c}\text { Top } 20 \\
\text { amount } \\
\text { proport-ion }\end{array}$ \\
\hline 2007 & 5.44 & 2.3900 & 3.66 & 4.41 & 4.72 & 4.94 & $67 \%$ & $81 \%$ & $87 \%$ & $91 \%$ \\
\hline 2008 & 23.16 & 9.1878 & 18.00 & 19.80 & 20.83 & 21.47 & $78 \%$ & $85 \%$ & $90 \%$ & $93 \%$ \\
\hline 2010 & 12.77 & 2.3803 & 7.46 & 9.42 & 10.51 & 11.28 & $58 \%$ & $74 \%$ & $82 \%$ & $88 \%$ \\
\hline 2011 & 13.29 & 2.9173 & 7.85 & 10.27 & 11.59 & 12.16 & $59 \%$ & $77 \%$ & $87 \%$ & $91 \%$ \\
\hline 2012 & 10.67 & 1.6590 & 4.56 & 6.08 & 7.12 & 7.92 & $43 \%$ & $57 \%$ & $67 \%$ & $74 \%$ \\
\hline 2013 & 17.09 & 1.4450 & 5.47 & 7.22 & 8.66 & 9.90 & $32 \%$ & $42 \%$ & $51 \%$ & $58 \%$ \\
\hline 2014 & 32.28 & 2.5023 & 9.80 & 13.40 & 15.48 & 16.86 & $30 \%$ & $42 \%$ & $48 \%$ & $52 \%$ \\
\hline 2015 & 77.49 & 6.1625 & 22.17 & 33.89 & 42.77 & 48.39 & $29 \%$ & $44 \%$ & $55 \%$ & $62 \%$ \\
\hline 2017 & 349.48 & 12.5900 & 37.65 & 60.03 & 78.69 & 94.67 & $11 \%$ & $17 \%$ & $23 \%$ & $27 \%$ \\
\hline 2018 & 1600.10 & 40.5900 & 171.85 & 288.01 & 375.41 & 453.34 & $11 \%$ & $18 \%$ & $23 \%$ & $28 \%$ \\
\hline 2019 & 318.16 & 9.4200 & 35.39 & 48.64 & 57.95 & 64.51 & $11 \%$ & $15 \%$ & $18 \%$ & $20 \%$ \\
\hline
\end{tabular}


in the market. But in particular, the goodwill impairment losses in 2018 and the year before and after showed a sharp growth and decline respectively, indicating that in 2018, Chinese listed companies appeared a phenomenon of centralized provision for large impairments, and the goodwill impairment test showed an imbalance in market self-adjustment.

\subsection{Distribution of Goodwill Impairment Industry}

The risk of goodwill is macroscopically controllable, but for some industries, it accounts for too much. The scale of goodwill is calculated by industry, and the results are shown in Table 5.

Table 5. Scale of goodwill in various industries by 2019 (100 million yuan)

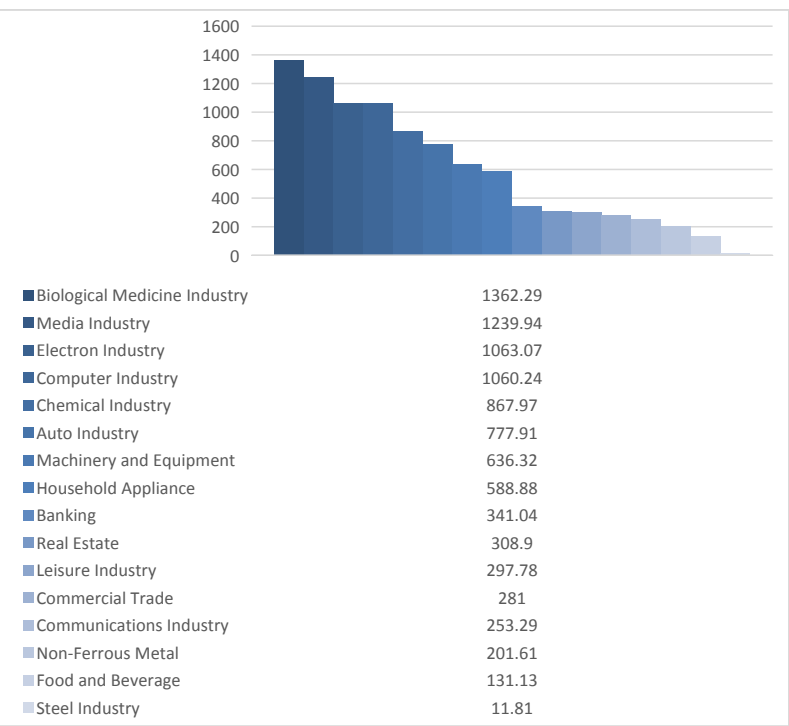

It is not difficult to see that high goodwill industries mostly include medicine, media, computer and other emerging industries. Emerging industries are still in initial development, whose goodwill generally makes striding growth, but a slight accident is a fatal blow. For example, in 2017, the value of goodwill among the top 50 listed companies reached 25.509 billion yuan, with an average of more than 500 million yuan. From the perspective of ranking, the top 10 listed companies have incurred a total goodwill impairment of up to 14.367 billion yuan and realized a net loss of 17.9 billion yuan. Meanwhile, it reflects that the excessive autonomy of corporate managers over the amount of goodwill impairment.

\subsection{Performance Impact of Goodwill Impairment}

In addition to being directly reflected in financial statements, goodwill impairment will also have an intuitive impact on corporate performance, like corporate performance assessment, follow-up financing, customer evaluation, etc., among which the financial indicator with the most extensive impact is net profit.

The analysis of the above table shows that in the group with influence degree $<0$, the reason why the ratio is $<0$ is that the net profit of the group has been negative before the provision for impairment, that is, the absolute value of the average impact degree of the group is positively correlated with the impact of goodwill impairment loss. In the group with influence degree of $0-0.2$, the number of companies is the largest, while the number of companies in the remaining group is lower. It is worth noting that the group with the degree of impact $>1$ means the net profit of the current period is less than the goodwill impairment loss, that is, the enterprise changes from profit to loss, which directly leads to negative performance.

Table 6. Degree of performance impact of goodwill impairment ${ }^{\mathbb{D}}$

\begin{tabular}{|c|c|c|c|c|c|c|}
\hline $\begin{array}{c}\text { The degree of } \\
\text { impact of goodwill } \\
\text { impairment on net } \\
\text { profit * }\end{array}$ & $\begin{array}{c}\text { Number of list- } \\
\text { ed companies in } \\
\text { the group }\end{array}$ & $\begin{array}{c}\text { Mean influence } \\
\text { degree within the } \\
\text { group }\end{array}$ & $\begin{array}{c}\text { Total goodwill } \\
\text { impairment loss } \\
(100 \text { million } \\
\text { yuan) }\end{array}$ & $\begin{array}{c}\text { The proportion of } \\
\text { goodwill impair- } \\
\text { ment loss }\end{array}$ & $\begin{array}{c}\text { Book value of } \\
\text { goodwill calculat- } \\
\text { ed at the advanced } \\
\text { point (100 million } \\
\text { yuan) }\end{array}$ & $\begin{array}{c}\text { The proportion of book value } \\
\text { of goodwill calculated at the } \\
\text { advanced point }\end{array}$ \\
\hline$<0$ & 37 & -1.2708 & 26.46 & $26.14 \%$ & 135.15 & $7.35 \%$ \\
\hline $0-0.2$ & 247 & 0.0505 & 37.34 & $36.88 \%$ & 1478.39 & $80.45 \%$ \\
\hline $0.2-0.4$ & 31 & 0.2665 & 13.77 & $13.60 \%$ & 102.51 & $5.58 \%$ \\
\hline $0.4-0.6$ & 14 & 0.4916 & 8.10 & $8.00 \%$ & 47.63 & $2.59 \%$ \\
\hline $0.6-0.8$ & 5 & 0.6857 & 3.54 & $3.49 \%$ & 34.09 & $1.86 \%$ \\
\hline 0.81 & 2 & 0.9013 & 2.99 & $2.96 \%$ & 7.34 & $0.40 \%$ \\
\hline$>1$ & 5 & 6.1738 & 9.03 & $8.92 \%$ & 32.50 & $1.77 \%$ \\
\hline Summation & 341 & -0.0468 & 101.24 & $100 \%$ & 1837.60 & $100 \%$ \\
\hline
\end{tabular}

Note: $*$ The following two formulas are used as analytical indicators to investigate the impact of goodwill impairment on net profit: the impact of goodwill impairment on net profit = goodwill impairment loss recognized in the period / net profit before impairment provision; net profit before impairment provision $=$ net profit + goodwill impairment loss recognized in the period.

(1) Data sources are financial statements of all listed companies in 2016. 
The average influence degree within the group reflects the average influence level of goodwill impairment loss on net profit of the group. As we can see, except for $<0$ group and $>$ group 1, the mean value of all other groups is within $(0,1)$, and the negative total value is mainly affected by $<0$ group, so that in the case of negative net profit, the use of goodwill impairment to exaggerate loss is consistent with surplus management.

Analysis of each category of goodwill impairment loss ratio and goodwill book value before accounting period, can be found that the two are not consistent, especially in the $<0,0-0.2$ and $>1$ groups, there is an inverse relationship of "one high and one low", namely the goodwill of high impact on net profit group largely confirmed a huge goodwill impairment loss.

Overall, the greater impact of goodwill impairment on performance of listed companies is, the greater proportion of impairment is, while companies with less impact tend to recognize high goodwill but make little or no goodwill impairment, which fully reflects the current goodwill accounting standards in China is not perfect, goodwill impairment implementation is not in place and market regulation is not comprehensive.

\section{Suggestions on Goodwill Impairment of Listed Companies}

\subsection{Clarify the Normative Impairment of Guide- lines}

The current standards are ambiguous in positioning of goodwill impairment test of listed companies and have low operability. For example, the specific method and corresponding basis of asset group division are not clearly defined. Moreover, impairment measurement is inevitably subjective, but accounting standards lack relevant restrictions and operating norms, which gives listed companies more freedom to operate data.

Therefore, the standard operation of goodwill impairment in the criterion should be clarified, such as estimating the overall profitability and subsequent cash flow of the industry as a unit, measuring the average goodwill scale, publishing relevant data and serving as industry reference, and limiting the floating level range of goodwill impairment in the industry, so as to avoid the sudden huge losses of listed companies. At the same time, unified evaluation standard can be adopted in the criteria to limit the premium rate range of M\&A goodwill during the initial measurement of goodwill, in order to avoid the existence of huge goodwill at source and reduce the risk of goodwill impairment test.

\subsection{Enhance External Supervision}

In the context of imperfect development of China's capital market, it is of great significance for external regulatory authorities to intervene when the market is unable to adjust itself.

First, during the initial goodwill measurement, the regulators should get to know the basic situation to avoid high premium because of the blind optimism, like the acquiree's operating capacity, credit rating, debt level and so on, and combine with the specific industries to estimate the maximum acceptable premiums to provide judgment for subsequent performance. Secondly, the regulatory authorities should make recommendations for the modification of the performance commitment agreement in the merger clauses to minimize or even eliminate the situation that the blindly exaggerated growth rate is inconsistent with the actual business capacity of the enterprise. Finally, the regulatory authorities should also supervise other relevant departments to see if there is any unreasonable behavior, such as strengthening the supervision of certified public accountants, the review of asset appraisal institutions and so on.

\subsection{Improve the Synergy of Mergers and Acquisi- tions}

Enterprises can improve the synergy effect from three aspects to reduce risks.

On the one hand, the listed company shall have effective internal control management system, risk management mechanism and project development planning to ensure its operation qualifications and profitability reaching a desired level, and can bear the risk of stock price decline due to unfavorable factors including goodwill impairment in the M\&A projects. Also, they should be according to their own development plan to promote M\&A projects, rather than blindly follow market trend. On the other hand, listed companies should pay close attention to the relevant information of the acquiree before the acquisition, prudently predict the synergy effect and impairment risk, comprehensively evaluate the existing capabilities and future prospects of the target company combined with the enterprise development needs and requirements. With the help of a professional assessment organization of independent judgment on the business and cost, enterprises can make a careful decision to reduce the risk of goodwill impairment. Finally, the listed company should continuously follow up the cooperative integration of both parties after the merger, including the stability of operation ability, the competitiveness of innovative business, the continuity of profit level, the rationality of resource allocation and the consistency of 
financial system. Only in this way can the two parties make better use of the synergy effect, create excess profits and reduce the risk of impairment.

\subsection{Explore Optimal Measurement Methods}

Goodwill impairment and amortization have their own advantages and disadvantages, are also questioned respectively.

Although the impairment test method is rigorous and operable, it has high execution cost, and the cover effect caused by the net value makes the book value of goodwill overestimated, resulting in the management unable to take corresponding responsibility for its decision.

The amortization of goodwill can reflect the consumption of goodwill effectively, but the usefulness of its accounting information is questionable, and the determination of the amortization period and the amortization method does not reduce the cost.

Therefore, IASB stated in the preliminary opinion that both impairment and amortization, two accounting treatments of goodwill, have limitations. Currently, there is no impairment test that can directly test goodwill, and it is difficult for amortization to estimate its useful life and consumption loss pattern. So a combination of the two might work. In the regular business cycle of listed companies, goodwill is generally consistent with it. In this case, the use of systematic amortization method can reduce the annual cost of goodwill impairment test, and meanwhile limit enterprises' behavior of using goodwill to whitewash statements in normal operations. For significant matters that affect a company's reputation, impairment test can be used to accurately reflect the book value of goodwill. Besides, for the impairment test of goodwill, it is feasible to optimize the asset group identification, simplify the recognition of recoverable amount, and allow the use of after-tax cash flow and after-tax discount rate in estimating the value in use.

\section{Conclusion}

The current economic growth rate has fallen again, and various indicators are developing steadily, but the prospect is worth worrying about. In this economic downturn, enterprises may not be able to bear the economic consequences of the goodwill impairment provision. It can be seen that the subsequent measurement of goodwill is only the final result of multi-party game under different economic environments.

In view of the high book value of goodwill and fre- quent occurrence of black swans among listed companies in China in recent years, through essential exploration and data disclosure, this paper puts forward suggestions on clarifying impairment standards, enhancing external supervision, improving the synergy effect and exploring optimal measurement methods. It is noteworthy that the accounting standards related to the subsequent measurement of goodwill, as the financial standards of enterprises, are essentially trying to help enterprises take off the "sin cap" they have put on.

\section{References}

[1] P.D. Leake. Goodwill: Its Nature and How to Value it[M]. New York: Gee \& Company, 1914.

[2] Yan Hongyu. Goodwill Accounting[M]. Beijing: China Economic Press, 1999.

[3] Richard D. Irwin. Business valuation, Goodwill and the super-profit method[J]. Studies in Accounting Theory, 1962:201.

[4] W.a.aton. Accounting Theory[M]. New York: The Ronald Press Company, 1922.

[5] Eldon S Hendriksen. Accounting Theory[M]. 4thed, Homewood, Illinios: Richard D. Irwin, Inc., 1982.

[6] Huang Wei, Tang Xiangxi. Whether amortization should be reconsidered to improve the goodwill follow-up measurement[J]. Exploration on Economic Issues, 2018(08): 39-66.

[7] Guo Ruina. Analysis on the Nature of Goodwill based on the Synergetic Effect Theory [J]. Commercial Accounting, 2012(05):87-88.

[8] Wang Jiancheng. Recognition of the Nature of Core Goodwill Assets [J]. Times Accounting,2002(04): 5253.

[9] Wang Jing. Consideration of Recognition and Measurement based on the Nature of Goodwill [J]. Finance \& Accounting Communications, 2015(25): 9093.

[10] Zhang Xinyuan, Xu Jiangjun. Thinking about Accounting Treatment of Goodwill -- a Case Study based on 263 Goodwill Impairment [J]. Finance and Accounting, 2017(17):28-30.

[11] Zhang Naijun. Don't Let Goodwill become "The Emperor's New Clothes" -- A Rational Analysis on Goodwill Treatment [J]. Friends of Accounting, 2016(18):2-5.

[12] Tan Yawen. Study on the Accounting Treatment of Consolidated Goodwill[J]. Business News,2019(10):169. 